\title{
21世紀に 科学の向からところ
}

特別インタビュー

この 20 年間の科学技術の躍進は研究の高度化·複雑化をもたらしたが、科学の本質を見極める力はますます重要になっ てきた。一方、アジアの台頭が価值の多様化を生み、成熟した社会は科学の文化的素養を必要としている。2001 年度ノー ベル化学賞受賞者で理化学研究所理事長の野依良治博士に、科学と科学者のあり方について、冬野いち子が話を聞いた。

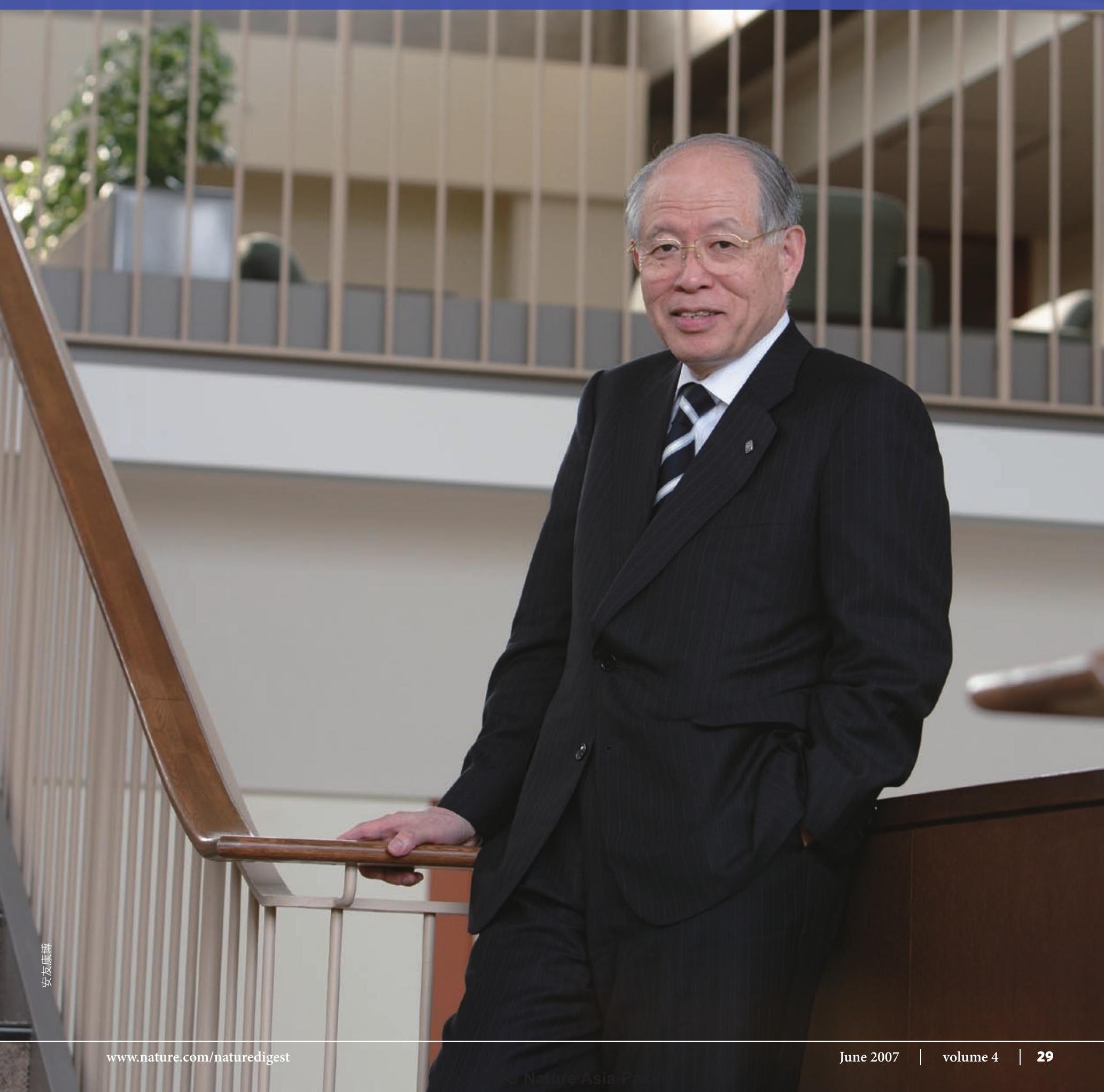




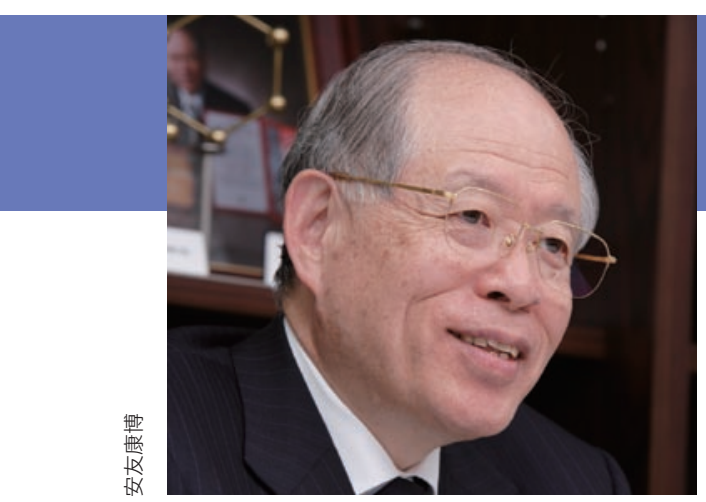

\section{分野を融合し、将来を見通す}

冬野一この 20 年間で、物理・化学・生物 など主な科学分野はどのように変わってき ましたか？

野依一科学は自然の森羅万象を客観的に記 述する学問です。20 世紀は物理と化学を中 心とした、自然を客体としてとらえるサイエ ンスが主流でした。しかし 20 年前ごろから、 生命科学、特に分子生物学的なアプローチ が非常に盛んになり、人間自身も研究対象 となってきました。脳科学などの進歩によっ て、身体だけでなく精神や心などに関して も科学的なアプローチがとられるようになり ました。最近、特にその傾向があると思っ ています。いずれにしても、物理、化学、 生物なぞ一面的な見方ではなく、統合しな いと自然の理解は不可能になってきました。 宇宙、生命、物質、情報などは、知識の統 合なくして理解はありえない。さらに、自然 科学と人文科学の統合も必要です。

冬野一それは容易にできることでしょうか？

野依一いいえ、分野間の融合は非常にむず かしく、むしろ実際には、分野の細分化・知 識の断片化のような色彩が強くなってきたこ とをたいへん恐机ています。分野の融合は 極めて重要ですが、いったん細分化したも のを統合するのはなかなか困難です。これは、 教育の問題に帰結するのではないか、と考 えています。自然と正面から向き合うことな く、細分化した分野を先端科学と称しながら 研究を行っている。若い人はまず、人間とし ての教養を身につけなけ机ばなりません。あ まり早くから専門教育をしないことが大事で すが、今のような状況であればやむを得な いので、多様な専門家たちが同じテーブル について、物事を考えることが必要でしょう。 冬野一そのほかにありますか？

野依一もうひとつ、将来を見通すことが非

野依良治 (のより・りようじ) / 理化学研究所理事長。工学博士。1938 年、兵庫県生まれ。1961 年、京都大学 工学部工業化学科卒業。1 963 年、同大学大学院修士課程修了。1972 年、名古屋大学理学部教授。1997 年、同 大学大学院研究科長・理学部長。2001 年、「キラル触媒による不冏反応の研究」においてノーベル化学賞受賞。 2003 年 10 月より現賗。自ら提唱した、野依イニシアチブ (見える理研、科学技術史に輝き続ける理研、研究者 がやる気を出せる理研、世の中の役に立つ理研、文化に貢献する理研)をもとに、理研の運営に力を注いでる。

常に重要になってきています。今までの科 学は「証拠がないことは絶対にいわない」 という証拠主義でした。今後もサイエンス 自体は証拠主義で推移する面があると思い ますが、それに基づく技術の開発になると、 公共性を意識し将来を見通すことが大切で す。幸い、計算機が発達してきたので、非 常に大きなデータベースと確実な原理があ れば、信頼性のあるシミュレーションがで きます。こうした未来予測というのは、人 類社会にとってほんとうに大事になると思 います。環境、エネルギー、医療、福祉、 安全などに関する研究は、必ずしも利益を もたらすとは限りませんが、これらを十分 に推進していく必要があります。こういっ た正統性ある研究の中から、事業性や採算 性が生まれる可能性もあると思っています。

\section{科学を表現する}

冬野一研究者と社会とのかかわり方も変 わってきていますか?

野依一私は、科学と社会のかかわりは時代 の宿命だと思っています。自然科学の研究 の本質は知識の創造で、社会とあまり関係 がないように思われていますが、私はけっ してそうは思いません。自然科学の研究で いちばん大切なことは、社会を啓発するこ とです。科学は、宇宙の誕生や生物の進化 など、私たちを取り巻くものについて客観 的に教えてくれます。こういう知識を得る と、人は自分がいかにささやかな存在であ るかを知り、まっとうな人生観・自然観を もち、謙虚になります。これが自然科学の 最大の意義であり、科学技術や経済への効 果を超えて大切です。研究者はそういった ことを主張し、説得しないといけない。

冬野一しかし、その積極性が研究社会に不 足していると?

野依一そのと㧍りです。自然科学の研究は 依然として「記述」にとどまっています。 これをいかに「表現」していくか、というこ とが大事です。芸術一絵画、建築、文学な ど多くの知的な活動は記述もしていますが、 表現力があります。だから人の心を打つわ けです。音楽だって譜面をもとに歌手や演
奏者、指揮者、オーケストラがいて表現す るから人々にわかる。こういったプロセスや 方法、スキルが科学にはありませんね。サ イエンスは人類にとって本質的なものです。 研究成果を学術論文や特許といった記述に とどまらず、表現しなくてはいけない。

冬野一どのような形で表現すればいいでしょう? 野依一それは未知の部分です。しかし大き な未開の分野だろうと思います。科学者社 会と一般社会が「これがすばらしい」と思 えば、政策や慈善家などいろいろなものが 後押ししてくれるでしょう。科学者だけで はできないので、新しい種類の技法が必要 です。科学の本質ゆえに、将来の発展性が すごくあると思います。科学インタープリ ター*というのは表現のひとつの手段です。 しかし、その科学インタープリターも現状 では、研究成果を直訳か意訳している程度 のものだから、もっと大きな伝え方がある と思います。芸術、文学が嫌いという人は いません。でも、科学が嫌いだという人は います。扔かしですね。私は、自然にか かわる科学の本質が嫌いな人はいないと 思っています。科学の表現は、21 世紀前 半の非常に大きな課題だと思っています。

\section{価値の多様性とアジア}

冬野一科学技術はますます高度化が進み、 研究のスピードも速くなっています。競争 力を保つために、科学者はどのような意識 をもつべきでしょうか？

野依一Nature 誌は著者の国籍を問わず、す ばらしい研究成果であれば揭載しています ね。しかし、逆に Nature 誌に揭載されない 論文は意味がないのでしょうか。過去の長 い間、欧米先進国が科学技術研究を先導し、 日本もそれに加わりました。今後もしばらく はそうであろうと思います。欧米や日本は、 アカデミックな意味での科学のフロンティア を切り開くことに最大の関心があると思いま す。だけど、アジア諸国の情勢は少し違い ます。もちろん、先端科学に関心をもって いますが、水、エネルギー、食糧そして貧 困など、より深刻な社会的・地球的規模の 問題に直面しています。そして、これらの 


\section{SPECIAL $20^{\text {th }}$ ANNIVERSARY FEATURE}

解決、軽減にかかわる科学の役割は大きい。

冬野一たしかにそうですね。

野依一しかし、Nature 誌の主なプレーヤー たちはこういうことに対して関心が薄いの ではないか、アジアの 1 人の研究者である 私にはそう思えます。既成の科学知識の修 正・改良、あるいは類似の知識の再生産で はなく、人類の生存にかかわる問題に正面 から向き合わなければならない、と思って いるのがアジアの人たちの正直な気持ちで す。競争は価值観の画一化をもたらします。 しかし、今求められているのは価值の多様 性です。私は、競争をあおることは少し見 方が狭いと思います。もっと視野の広い俯 瞰的なものの見方が、世界中の科学社会に 求められているのではないでしょうか。 冬野一アジアの国の中には、競争を助長す る政策を取っているところもあります。

野依一そうですね。研究者社会を構成する 人々の意識改革をしなければいけないです ね。「我々は何のために科学をやっているの か」という科学の本質を再認識することが必 要です。Nature 誌に期待するところ大です。

\section{文化としての科学}

冬野一話は変わって、教育について㧈うか がいします。理科離れといわれて久しいです が、科学技術教育はどうあるべきでしょうか？ 野依—「青少年の科学技術に対する意識が 低下している」という批判は、部分的に的 を射ていると思います。しかし、日本の大 人の科学技術リテラシーは世界最低レベル です。子どものレベルよりずっと低いです。 これが何を意味するのかというのを考えな ければいけません。理科をする心は、人生 80 年を生きるための糧です。実世界で幸 せに生きるための理科。自然を知り、自分 の生きている位置を知ることができる。こ れが大事ですが、今の理科はそうなってい ません。文化は人間の心の拠りどころと して非常に大切で、その要素のひとつとし て科学があります。あまり小さいときから 理科系、文科系と分けてはいけない。人間 というのはもともと文化的な生き物ですか ら、ひとつの大きな人間性を作っていくた
めに科学が必要です。科学を職業としない 人たちも、きちんとした教養人であるため には科学の素養が必要だと思います。そう いう位置づけで理科をやらないと、国をつ くるしっかりした教育はできません。

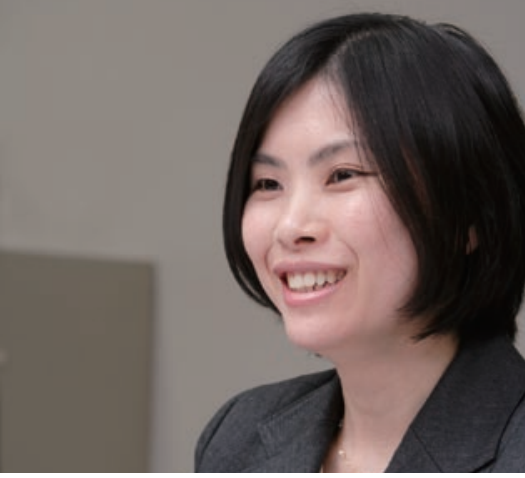

\section{研究の異端児であれ}

冬野一教育と並んで最近問題になっている のが、研究不正や倫理問題です。研究者が もつべき意識も変わってきていますか？

野依一研究者の社会は非常に保守的で、新 しいものをなかなか受け入れようとしませ ん。問題は、その研究社会が間違った意味 での民主主義を取り入れて、多数派主義に なっていることです。本当の意味での独創 的な研究は、本来少数派です。私は研究者 に「異端研究をやれ」とよくいいますが、 保守化した研究社会では、人事や研究費採 択も多数決で決められています。学術研究 は多数決で物事を決めるべきではないと思 います。少数派であることを恐れるべきで はない。本来、独創的な大研究は少数派に 属していて、年月を経て真価が明らかに なって多数派になります。しかし、短期的 に有名学会やNatureのような雑誌がもて はやされています。問題は、科学の本質を 理解できない権力者、さらに研究社会自身 が、雑誌名あるいは論文数・引用数などに よる評価を偏重することです。

冬野一そういうところに、デー夕のねつ造・ 改ざんや論文不正の原因のひとつがあると？

野依一ええ。しかし、結局は科学研究の 本質に戻ると思います。真摰に自然と向き 合って研究するというのが科学研究の基本 です。デー夕の称つ造・改ざんや論文不正 は私には理解できません。そんなことをし て何が楽しいのかと思います。全体的にみ ると、不正行為にかかわる研究者はごく一 部であり、ほとんどの研究者は今までどお り良心的にやっていくでしょう。大学など には必要以上のプレッシャーをかけるょり、 自然に研究ができる雾囲気を作るべきで す。再現性の問題もよく問われていますが、 実験結果はいつも再現されるとは限りませ ん。測定技術の精度や材料の純度の問題も
あります。亜鉛の中にちょっと鉛が混入し ていることが、化学反応によかったりしま す。間違いを恐れることはありませんよ。 冬野一最後に、Nature やNPG ネイチャー アジア・パシフィックに関する思い出と、今 後に期待することがあればお聞かせください。 野依一私は、一科学者としてはNature 誌 にあまりかかわってきませんでした。一度投 稿して一度採用されただけです ${ }^{1}$ 。あまり投 稿しなかったのは、仲間が一般誌より専門 誌を読むからという理由だけです。Nature 誌は生命科学の論文が多いので、理解でき るものが少ないというのが正直な告白です が、科学界の情勢に関するニュース記事な どが多く載っているのはたいへん参考にな ります。Natureには、引き続き科学社会を リードするオピニオン・リーダーとしての役 割を果たしてほしいです。ただ、申し上げ たいことは、アジアの台頭により社会・地 球規模の問題に課題が移ってきているので、 アジア諸国が科学に何を望んでいるのかを 十分勘案してほしいということです。近代 科学は西洋の還元主義によって先導されて きましたが、それだけでは解決できない問 題が起こってきています。分析だけでなく、 総合的に物事をとらえることが不可欠に なっています。アジアの科学者たちの本来 の思想・哲学や動きを注意深く見守りなが ら、Natureには発展していってほしい。そ の意味でも、NPG ネイチャーアジア・パ シフィックに期待するところは大きいです。 冬野一ありがとうございました。

\section{* 科学インタープリター}

比較的新しい職業のジャンルのひとつで、複雑かつ難解 な科学の世界を一般の人々にわかりやすく伝えることを 役割とする。

1. Jessop, G. P., Ikariya, T. \& Noyori, R. Homogeneous catalytic hydrogenation of supercritical carbon dioxide. Nature 368, 231-233 (1994). 